\title{
The Civic Dimension of School Voucher Programs
}

\author{
Cullen C. Merritt, Ph.D.* \\ School of Public and Environmental Affairs \\ Indiana University-Purdue University Indianapolis \\ merritt1@iupui.edu
}

Sheila Suess Kennedy, J.D.

School of Public and Environmental Affairs

Indiana University-Purdue University Indianapolis

shekenne@iupui.edu

Morgan D. Farnworth

School of Public Affairs and Administration

University of Kansas

mfarnworth@ku.edu

Authors' copy (*corresponding author)

Forthcoming at Public Integrity

Accepted October 28, 2018 


\title{
The Civic Dimension of School Voucher Programs
}

\begin{abstract}
America’s public schools have not been exempt from the movement to privatization and contracting out that has characterized government innovations over at least the past quarter century. A number of the issues raised by school voucher programs mirror the management and efficacy questions raised by privatization generally; however, because public education is often said to be “constitutive of the public," using tax dollars to send the nation's children to private schools implicates the distinctive role of public education in a democratic society in ways that more traditional contracting arrangements do not. Using a content analysis, the authors explore the extent to which school choice voucher programs are mandated by state statutes to integrate civics education into their curriculum. Findings reveal that across the fourteen states (and the District of Columbia) that have enacted school choice voucher programs, statutes exempt these programs from curriculum oversight, including civics requirements, and grant them considerable autonomy in designing their curricula. This study concludes by discussing the implications for ethical and accountable governance when primary and secondary schools fail to cultivate civic competence and civic literacy.
\end{abstract}




\section{INTRODUCTION}

The United States is among the world's most diverse countries and is comprised of many different ethnicities, races, and religions with different histories and cultural antecedents (Morin, 2013). In former times, those differences were countered to some extent by widely shared cultural experiences such as reading the daily newspaper, discussing programs that aired on one of three television broadcast networks, registering for the military draft, or attending public schools (Kennedy, Braun, and Tynes 2011). In an increasingly differentiated, "niched”, and privatized social landscape, Americans no longer have those or many other avenues to social cohesion (Banting \& Kymlicka, 2017). The resulting fragmentation has made knowledge of the history and philosophy of the nation's governing institutions increasingly important, because in the absence of other commonalities, shared understandings of the nation's governing documents and founding principles operate as a common language or "civil religion” (Bellah, 1967) and provide a frame of reference necessary for genuine political communication and participation. Citizens who lack basic knowledge of the nation’s legal, ethical, and philosophical framework are unable to assess whether the performance of their elected officials is consistent with the principles of the United States' founding documents.

Both democratic self-government and ethical public service require a measure of what scholars have dubbed “constitutional competence” (Newbold, 2011; Rosenbloom, 1992; Rohr, 1998). Deficits in civic literacy have been linked to harmful consequences for fields such as science, religion, and public education, as well as for the personal empowerment of individuals (Kennedy, 2001; Westheimer \& Kahne, 2004; Prothero, 2007). A number of organizations and educators are engaged in efforts to improve civics education in the nation's public schools. 
Broad agreement on the importance of this issue is reflected in the inclusion of civics education in the standards governing public education in 40 states (Shapiro \& Brown, 2018). To date, however, research has not explored the extent to which state-level school choice voucher programs that enable growing numbers of the nation's children using taxpayer dollars to attend nonpublic schools are legally required to engage in civics education similar to their government counterparts.

In this study, the authors describe the connection between public value creation and school voucher programs, analyze the relevant data (i.e., state statutes) using content analysis methodology, and evaluate the extent to which voucher programs are legally required to advance civic literacy. Given the importance of civic literacy (Westheimer \& Kahne, 2004; Prothero, 2007), the study concludes by considering the desirability of requiring voucher programs to include civic education.

\section{PUBLIC VALUE CREATION AND SCHOOL VOUCHER PROGRAMS}

Public value creation is defined as "producing what is either valued by the public, is good for the public, including adding to the public sphere, or both, as assessed against various public value criteria” (Bryson, Crosby \& Bloomberg, 2014, p. 448). Public managers may create public value by “deploying the money and authority entrusted in them to produce things of value to particular clients and beneficiaries” while "establishing and operating an institution that meets citizens' (and their representatives') desires for properly ordered and productive public institutions” (Moore, 1995, p. 52). The inculcation of civic knowledge, defined as an understanding of the 
legal and political environment within which public decisions are made, and within which the ethical propriety of those public decisions must be evaluated, is one such public value.

The combination of inputs, processes, outputs, and outcomes that create public value is a growing focus of public administration scholars and practitioners (Bryson, Crosby \& Bloomberg, 2014; Van der Wal, Nabatchi \& de Graf, 2015). Despite the complex networked and crosssector arrangements integral to public value creation, the literature posits that government remains the primary mechanism through which public value is created (Bryson, Crosby, Bloomberg 2014; see also Denhardt, Denhardt \& Blanc, 2006). Government seeks to facilitate the creation of public value across sectors through political authority mechanisms such as laws, regulations, or policies (Bozeman, 1987). For example, government often seeks to rectify negative externalities, spillover effects, inefficient markets, and inequitable distribution of goods and services (Samuelson, 1954; Bator, 1958; Bozeman, 2000). Government, by exercising its political authority, can even elicit certain positive organizational outcomes necessary to public value creation from private organizations, which are increasingly integral to the creation of public value and advancing the public good (Moulton \& Feeney, 2010). However, legal and regulatory instruments enforced by government may be inadequate to address social ills (Downs \& Rand Corporation, 1967; Lindblom, 1977), including in certain instances when private organizations maintain considerable autonomy and discretion over the objectives they prioritize.

America's public schools have been important creators of public value across sectors (Langton \& Jennings, 1968). However, concerns about failing schools, especially in America’s poor urban neighborhoods, have triggered a number of reform efforts, including school voucher programs in which government agencies issue certificates to parents/guardians to enroll their 
children in participating schools chosen by the parent/guardian. These participating schools are paid a predetermined amount for each voucher student enrolled (Levin, 2002). The vouchers are used at private schools, many of which are religiously affiliated. In most programs, vouchers are awarded through a lottery system, in which eligible students—usually but not always determined on the basis of socioeconomic status—are pooled, and recipients chosen at random (Peterson, Greene, Howell, \& McCready, 1998). School choice programs of various designs are also present outside the United States, as evidenced by reforms in Great Britain, Chile, New Zealand, and Sweden, among other countries (Heyneman 2009). Speaking specifically about this international context, Heyneman notes that "it is normal for government to deliver public education through religious schools, as long as the religions do not threaten values of the wider community” (91).

Voucher programs have generated complicated ethical, legal, and policy debates as well as a number of lawsuits. The debates are largely between those who believe that education is a consumer good—and that private schools can offer valuable skills that will be needed in the job market—and those who argue that education is primarily a public good (Carnoy \& McEwan, 2003; Patrick, 2013) and that many private schools are ill-equipped to fulfill education’s public mission. Proponents maintain that vouchers create a market-based educational system in which schools must compete for students, a process they believe incentivizes innovation and positive academic outcomes (Belfield \& Levin, 2005). That belief is based upon economic models of supply and demand in which competitive markets have been shown to benefit consumers; it ignores, however, the civic mission of education (Carnoy \& McEwan, 2003; Patrick 2013). 
Furthermore, schools are inherently different from public organizations that seek only to create public value. Schools have as an important part of their mission a unique responsibility to transmit an understanding of public values (e.g., equity, the common good, protection of individual rights) to the next generation of policymakers, public servants, residents, and citizens (Guardian of Democracy: The Civic Mission of Schools 2011). In recognition of this responsibility, this study aims to identify the extent to which voucher programs are legally required to provide civics education. Such information may lay groundwork for scholarly insight into the impact of voucher programs on civic competence and knowledge.

\section{DATA AND METHODOLOGY}

To investigate the state of civics curricula in voucher programs, researchers used content analysis to examine germane laws and statutes of US states and the District of Columbia participating in voucher programs as of December 2017. Content analysis, according to Christie (2007), "involves the systematic coding of information in archival records. It is a research tool used to determine the presence of certain words or concepts within texts or sets of text” (176). The content analysis process begins by selecting texts from which information will be gathered (Christie 2007). Accordingly, state-level policies, such as state statutes and administrative code (hereafter referred to as "statutes") were the basis for analysis. Each statute is housed in a statespecific, publicly-accessible database. Even though federal regulations, including No Child Left Behind (NCLB) and the Every Student Succeeds Act (ESSA), prescribe(d) broad educational goals, development of K-12 curriculum is entrusted to the states. 
To identify the states with school choice voucher programs, the authors reviewed data from the National Center for Education Statistics (2017) and the Education Commission of the States (2017). Tables and figures in the appendix describe the states with school voucher programs; only states with an active school choice voucher program were included in this study. After identifying the fourteen states (and the District of Columbia) with active school choice voucher programs, the authors located and reviewed both the specific state statutes that created the voucher programs and state statutes related to K-12 education more broadly. From there, three lines of inquiry were explored: (1) statutes specific to civics curriculum in public schools, (2) statutes specific to civics curriculum in nonpublic schools, and (3) statutes specific to civics curriculum in school choice voucher programs. The extent to which voucher program participants are required to offer civics education was compared to regulations for public and nonpublic schools in those states where voucher programs are implemented. In other words, understanding the regulatory distinctions, if any, associated with civics education between voucher programs and their state-level public and nonpublic counterparts not participating in voucher programs provides a more holistic, contextual, and objective view of whether civics education regulations (or lack thereof) are unique to voucher programs.

After identifying statutes specific to public schools, nonpublic schools, and voucher programs, coding categories were objectively identified to ensure reliability and consistency across various statutes and multiple coders (see Christie 2007; Sabharwal, Levine, D’Agostio 2016). (It should be noted that not all nonpublic schools accept vouchers, and that participation in a state's voucher program can be conditioned upon compliance with regulations that would be legally impermissible if applied to private schools in general.) Specifically, a search included the 
following codes when examining civics requirements for each of the three school categories: civics, citizenship, and Constitution. With respect to school choice voucher programs specifically, the authors also reviewed the electronic collections of state statutes for the terms (not to be confused with codes) choice, voucher, education, disability as well as the specific name for a given state’s voucher program (see appendix for names of voucher programs). Because some voucher programs exclusively serve students with disabilities, the authors sought to be inclusive of statutes located outside of education-related chapters or sections.

During the content analysis process, two researchers examined pertinent statute excerpts and compared common regulatory themes (or trends) with respect to civics education across public schools, nonpublic schools, and school voucher programs. Throughout the content analysis process, codes were used as starting points for concentrated, substantive analyses of statutes. Researchers did not include excerpts containing codes that proved to be substantively unrelated to primary and secondary education; for example, statutes relating generally to civic organizations or amendments to state constitutions were not included in this analysis. After conducting these steps independently, inter-coder reliability was pursued through joint discussion of statutes; any discrepancies were resolved during this stage of the analysis process.

In reviewing civics curriculum requirements for public schools, nonpublic schools, and schools participating in voucher programs, clear trends emerged; these are discussed in the following section.

\section{FINDINGS: THE STATE OF CIVICS EDUCATION IN VOUCHER PROGRAMS}

The objective of the current study was to explore the extent to which private schools participating in voucher programs are required to offer civics education. The authors explored 
regulations pertaining to civics education in public schools, nonpublic school, and voucher programs in the fourteen states (and the District of Columbia) with active voucher programs as of December 2017. Even though the focus of the study is the degree to which voucher programs include a requirement that civics education be included in the curriculum, requirements applicable to public and nonpublic schools are included in order to offer comparative context.

Findings are discussed below and provide examples of specific language contained in statutes addressing civics education. The authors have focused considerable attention on the statutory language, because that language, drawn from a variety of states, reflects not only the extent to which legislative bodies emphasize civics education, but the nature of that civics instruction (e.g., testing, course requirements). This section begins by discussing civics education requirements for public and nonpublic schools not participating in voucher programs and concludes by comparing those requirements to those included in the regulations applied to schools participating in voucher programs. As noted previously, the Constitution limits the ability of states to impose curricular requirements on nonpublic schools, especially the religious institutions that comprise the majority of private schools. The courts have held that regulation of such schools must be "reasonable," which in practice has meant requirements safeguarding children's health and safety. The award of state accreditation, or participation in voucher programs, however, may be conditioned upon compliance with additional regulations and standards (Devins 1983).

\section{Public Schools}


All fourteen states (and the District of Columbia) associated with this analysis have codified social studies, including civics, as a core topic required for public schools. Some states identify civics and government as core topics. Indiana, for example, defines "core academic subjects” as including “(1) English, (2) Reading or language arts, (3) Mathematics, (4) Science, (5) Foreign languages, (6) Civics and government, (7) Economics, (8) Arts, (9) History, (10) Geography" (511 IAC 7-32-21, 2017). Other states require civics, government, and related subjects be taught within a specified core topic, such as social studies or global citizenship, among others. For instance, a Florida statute codifies its Next Generation Sunshine State Standards, which establishes the core content of curricula to be taught, and requires that social studies curricula include "at a minimum, geography, United States and world history, government, civics, humanities, and economics, including financial literacy”(Fla. Stat. §1003.41(2), 2017). Likewise, a Vermont statute requires that "each school shall enable students to engage annually in rigorous, relevant and comprehensive learning opportunities that allows them to demonstrate proficiency in...(d) global citizenship, including the concepts of civics, economics, geography, world language, cultural studies and history” (Vt. Admin. Code 7-1-2:2120.5, 2017). In addition to integrating civics education within their curricula, some states further emphasize the importance of civics curricula in public schools. According to a Utah statute, for instance,

The Legislature recognizes that a proper understanding of American history and government is essential to good citizenship, and that the public schools are the primary public institutions charged with responsibility for assisting children and youth in gaining that understanding” (Utah Code Ann. 53G-10-302(1)).

Of the states included in this study, all states, with the exception of Vermont, require a civics or related course (e.g., United States History, United States Government) as a public high 
school graduation requirement. For example, public high school students in Wisconsin are required to earn at least three credits in social studies, including instruction in state and local government, civics, economics, and history (Wi. Stat. §118.33(1)(a)1, 2017; Wis. Adm. Code P| 18.03, 2017). Similarly, a Louisiana statute mandates that all students attending public high schools receive "instruction in Civics and Free Enterprise as a prerequisite to graduation" spanning no less than two semesters, or one credit (La. R.S. Ann. §17:274.1, 2017).

Only five states (Arkansas, Florida, Louisiana, Utah, and Wisconsin) require a civics exam as a condition for receiving a high school diploma from a secondary public school. For example, Arkansas recently passed legislation, effective during the 2018-19 academic year, requiring public school students to "take a test that is identical to the civics portion of the naturalization test used by the United States Citizenship and Immigration Services; and correctly answer at least sixty (60) of the one hundred (100) test questions” as a condition for graduation (A.C.A §§ 6-16-149, 2017). Likewise, as of the 2016-17 academic year, a Wisconsin statute mandates passing of a civics exam as a requirement of a high school diploma. This exam is "comprised of 100 questions that are identical to the 100 questions that may be asked of an individual during the process of applying for U.S. citizenship by the United States Citizenship and Immigration Services" where the student must correctly answers at least 65 of those questions (Wis. Stat. §118.33(1m)(a)1, 2017). Some states, in lieu of a test focusing exclusively on civics, mandate that public schools administer an End-of-Course (EOC) assessment in social studies or history. For example, Florida students attending public schools are required to complete the U. S. History EOC assessment, which will constitute "30 percent of the student's final course grade” in that subject (Fla. Stat. §1003.4282(3)(d), 2017). Similarly, Louisiana 
students are required to score “approaching basic/fair” on the U.S. history EOC assessment to be eligible for a high school diploma (L.A.C 28.XI.6821, 2017). Of particular importance for this study, however, is the possible exclusion of civics competencies (on EOC assessments) that transcend instruction in U.S. history, including civic responsibilities, a review of constitutional principles, and a focus on civic engagement—what some consider markers of high-quality civics instruction (NCSS, 2013; Shapiro \& Brown 2018; Shon \& Hillman, 2015).

\section{Nonpublic Schools}

Of the fourteen states (and the District of Columbia) with active school choice voucher

programs, only five require civics or social studies instruction to be included in the curriculum of nonpublic schools applying for accreditation. For example, a Vermont statute extends civics curriculum requirements to all elementary and secondary students, regardless of their school's sectoral affiliation:

In public schools, approved and recognized independent schools, and in home study programs, learning experiences shall be provided for students in the minimum course of study. For purposes of this title, the minimum course of study means learning experiences adapted to a student's age and ability in the fields of...(2) citizenship, history, and government in Vermont and the United States" (16 V.S.A. § 906(a)).

In another example, a Maine statute notes,

American history, government and citizenship, including the Constitution of the United States, the Declaration of Independence, the importance of voting and the privileges and responsibilities of citizenship, must be taught in and required for graduation from all elementary and secondary schools, both public and private (Me. Rev. Stat. Ann. Title 20A, §4706, 2017). 
Despite curricular autonomy given to nonpublic schools in Indiana, the State Board of Education provides voluntary state accreditation and requires all schools seeking state accreditation, regardless of sector, to "provide instruction in (1) the Constitutions of Indiana and the United States in grades six through 12" in addition to "(2) the systems of government in Indiana and the United States, methods of voting, party structures, election laws, and the responsibilities of citizen participation in grades six through 12 for five full class periods within the two weeks preceding each general election” (IC §20-33-2-12). In a final example, a Louisiana statute notes "state approval of a nonpublic school is dependent on whether the school meets and maintains a sustained curriculum or specialized course of study of quality at least equal to that prescribed for similar public schools” (La. R.S. Ann. §17:11).

Other states explicitly exempt nonpublic schools from state oversight and accountability with respect to civics education. For instance, North Carolina legislation explicitly notes the lack of curriculum requirements for nonpublic schools, with the exception of national standardized testing (N.C. Gen. Stat. §115C- 549; N.C. Gen. Stat. § 115C-557). Further, North Carolina statute notes that "private church schools or schools of religious charter and qualifying nonpublic schools which comply with the provisions of N.C. Gen. Stat. §§115C-547 through 562 are not subject to any other educational provisions except requirements respecting fire, safety, sanitation and immunization” (N.C. Gen. Stat. §§115C-554, 562). The Indiana statute, despite its robust civics requirements for public schools, provides that "nonpublic, nonaccredited, and nonapproved schools are not bound by any requirements set forth in Indiana Code Titles 20 or 21 with regard to curriculum or the content of educational programs offered by the school" (IC §2033-2-12). 


\section{Voucher Programs}

In the fourteen states (and the District of Columbia) with active school choice voucher programs, statutes are explicit in indicating whether or not public and nonpublic schools are regulated with respect to civics education, whether it be curriculum, testing, or other aspects of instruction. Separate statutes pertaining to civics education exempt voucher programs from curriculum oversight and grant these programs autonomy in designing their curricula. Arkansas, for example, notes that "a school that participates in the Succeed Scholarship Program is not considered an agent or instrumentality of the State of Arkansas or a school district" and that "the curriculum and education plan for a student with a disability attending a private school is not subject to the regulatory authority of the State Board of Education” (AR Code § 6-41-807a and b, 2017). Similarly, Florida statute notes that participation in voucher programs "does not expand the regulatory authority of the state, its officers, or any school district to impose any additional regulation of private schools beyond those reasonably necessary to enforce requirements expressly set forth in this section," where those requirements largely pertain the health and safety requirements and not educational content (Fla. Stat. §1002.421(4), 2018). Furthermore, Florida’s voucher program legislation includes a caveat, in which "the purpose of this section is not to prescribe the standards or curriculum for private schools. A private school retains the authority to determine its own standards and curriculum” (Fla. Stat. 1002.395(1)(c), 2018). To be sure, voucher programs being exempt from state oversight with respect to curriculum does not mean that schools participating in those voucher programs do not offer civics education; findings are limited to the existence of state regulation on the subject. 
[Table 1 about here]

\section{DISCUSSION}

In analyzing civics curriculum regulations in the fourteen states (and the District of Columbia) with active school choice voucher programs, this study revealed that codified civics requirements are unanimously present for students attending public schools and required in five states for students attending accredited nonpublic schools; however, these requirements are not specifically extended to schools receiving public dollars by way of voucher programs.

The study's findings illuminate one of the most contentious issues raised by school voucher programs, the degree to which private schools participating in voucher programs retain their autonomy. It is one thing to respect the right of nonpublic schools to determine their own curricular choices when those institutions are independently or privately funded. When such schools choose to participate in a voucher program and to accept the public funding that accompanies such programs, legislators arguably have a legal and ethical obligation to ensure that the public is getting value for its dollars.

Schools play an essential role in advancing students' civic knowledge and developing a measure of what scholars (Rosenbloom, 1992; Rohr, 1998; Newbold 2011) have dubbed “constitutional competence", a process which begins with the teaching of America's history and the country's approach to and experience with the principles of democratic self-governance, such as an understanding of governmental structures and processes (Kennedy \& Schultz, 2011; Goals 2000: Educate America Act), and includes the transmittal of the country's core constitutional values (Congress, 1994; Rose \& Gallup, 2000). Those values are thought to cultivate civic dispositions, such as a sense of civic duty and concern for others (Shapiro \& Brown, 2018; 
Guardians of Democracy: The Civic Mission of Schools, 2011), and to guide appropriate individual participation in the United States' democratic system (Shapiro \& Brown, 2018, p. 16); equally important, a sound and accurate civics education should provide students with an understanding of the genesis and evolution of the rules that shape and constrain public service in the United States, and equip them with a standard against which to measure the performance of public officials and the bona fides of those who ask for their votes. At its best, civics education transmits the philosophical premises which undergird the Constitution and the Bill of Rights, premises which support a particular code of conduct for citizens, residents, and public servants alike-informing the socialization of the diverse students who constitute civil society (Troen, 1975; Ravitch, 1974). That code defines the public good as rights-driven, and situates public service in a world that is increasingly multi-sectoral, multi-cultural, and international in scope (Kennedy \& Schultz, 2011). Vartan Gregorian, President of the Carnegie Foundation, has written on the importance of increasing young people's “informed engagement" in their national life, a practice which requires school-based civic education: "after all, understanding and actively participating in our civic life was one of the principal missions given to American schools from the very beginning.” (Carnegie Corporation of New York, 2011).

According to the National Council for Social Studies (NCSS), sound civics curricula teach students to contribute appropriately to public processes and engage in civic practices, including voting, volunteerism, jury duty, and public deliberation (NCSS, 2013). Furthermore, civics education provides students with a framework for interaction with public actors and for playing an appropriate role in addressing policy issues: "because government is a means for addressing common or public problems, the political system established by the U.S. Constitution 
is an important subject of study within civics” (NCSS, 2013, 31). Beyond providing students with basic civic knowledge and skills, high-quality civic learning is associated with positive social outcomes including the promotion of civic equality (Fleming, 2011; Lopez et al. 2006; CNCS 2010), increased voter turnout and improvements in other forms of civic engagement (Sherrod, Torney-Purta \& Flanagan, 2010), and augmented social capital (Kahne, Chi \& Middaugh, 2006; Hooghe, 2004).

Because voucher programs funded with public dollars will likely continue educating a moderate portion of the American school-age population for the foreseeable future-and given the autonomy nonpublic schools possess in designing voucher students' curriculum—-this reality poses an essential question: do voucher programs facilitate effective civic education and literacy when they are not required to do so? While this question is beyond the scope of the current study and merits its own empirical assessment, it would be useful to suggest the ways in which private schools accepting vouchers could enhance civics education without necessarily requiring each school to develop and vet its own curricular approach. There are existing, well-developed courses available for adoption or adaptation. One widely-used curriculum that has been closely studied for a period of years and found to be extremely effective is We the People: The Citizen and the Constitution Program. Developed in 1987, the We the People education program is administered by the Center for Civic Education, a nonprofit, nonpartisan education organization; it was adopted by the Commission on the Bicentennial of the United States Constitution as the principal education program of the federal Constitution's bicentennial. The curriculum promotes civic competence and responsibility among elementary, middle, and high school students through "an innovative course of instruction in the history and principles of the U.S. 
constitutional democracy” (We The People: The Citizen and the Constitution, 2017, p. 2).

Through the curriculum, students gain insight into (1) the philosophical and historical foundation of the American political system, (2) how the framers created the Constitution, (3) how the Constitution has evolved to further the ideals contained in the Declaration of Independence, (4) how the values and principles embodied in the Constitution shaped American institutions and practices, (5) the rights protected by the Bill of Rights, and (6) the challenges the American constitutional democracy may face in the twenty-first century (We The People: The Citizen and the Constitution, 2017). These subjects match the goals of many, if not most, civic educators.

While the states in question have not signaled an intention to regulate voucher programs in the area of curriculum, it is worth considering what general oversight parameters might look like if states were to do so. One way to ensure desirable civics education outcomes in voucheraccepting schools would be for state governments to simply add a civics requirement as a condition of participation. Private schools participating in voucher programs might be required to demonstrate compliance with applicable civics education standards by maintaining records documenting class participation of voucher students in the civics curriculum in applicable grade levels on a yearly basis. Schools might also report voucher student performance in civics-related courses.

To date, research studies evaluating outcomes of the various voucher programs now in effect have focused upon general academic achievement, the consequences of diverting education funds from public schools in order to support private ones, and a variety of ethical and social equity issues including the racial and socio-economic identities of voucher recipients (Dynarski, 2016). Future research might build upon this study to assess whether voucher 
programs are creating constitutionally competent and civically literate students (see Galston 2007; Goss 1996; Johnson 2011; Kennedy and Schultz 2011; Rosenbloom 1992). Additionally, future studies might consider why specific states do not require civics education in voucher programs. Extensive research suggests that state legislatures, generally speaking, are reluctant to impede the curricular autonomy of voucher schools, which some consider a driver of quality, efficiency, and innovation (Finnigan, 2007; Lubienski \& Weitzel, 2010; Maxwell 2018; Stillings, 2006). However, the data reported in this study might better position scholars to look into the specific components of civics curricula that are voluntarily being implemented by voucher program participants, and any distinctions between such curricula within and across participating states, including the factors associated with civics curriculum adoption, whether those are political, demographic, or geographic (e.g., urban, suburban, or rural).

Lastly, the lack of civics requirements in school voucher programs speaks to a broader line of inquiry having implications for ethical governance. This line of inquiry may be captured by two questions: first, "what makes an organization or institution 'public'?” and, second, "what are the ethical responsibilities of those 'public' organizations?” Does acceptance of taxpayer dollars convert a private school into a public institution, or otherwise impose a duty to fulfill a public need or pursue a public purpose? If public financial support imbues a private school with at least some degree of publicness—if, in the absence of a legal mandate, it nevertheless imposes an ethical obligation to introduce students to the basic foundations of the regime providing such financial support—how far does that obligation extend, and how should it be effectuated? Future research focusing on the publicness and public purpose(s) of school voucher programs might 
clarify the ethical responsibility of participating educational institutions to offer meaningful civics education.

\section{CONCLUSIONS}

There are few issues in the public sphere that do not presuppose a civic understanding of, and general agreement with, a common purpose and shared vision of the public good (Kennedy 2001). Furthermore, the legitimacy of an electoral and constitutional system requires a civic consensus on the nature of ethical public service and the standards against which those ethics are to be measured. In the United States, that consensus is dependent upon at least a basic understanding of America's history and its Constitution and Bill of Rights. In light of the critical importance of civic knowledge and competence, the authors would argue that all students whose education is supported by tax dollars should receive a quality civics education. Some proponents of publicly-financed vouchers define the public purpose of education as the "achievement of a level of academic competence sufficient to sustain economic growth and make America competitive in the global marketplace” (Kennedy 2001, 455). Historically, however, as Benjamin Barber (2004) and others have pointed out, America's public schools have been seen as constitutive of the public. Creating a polity, forging a political community out of the nation's diverse elements, requires an education that goes beyond subject-matter focused solely on economic competitiveness and self-sufficiency (Kennedy, 2001). States choosing to implement voucher programs that send public funds to nonpublic schools have an obligation to see to it that the students who attend those schools are educated to participate in that polity. 


\section{REFERENCES}

Banting, K., \& Kymlicka, W. (2017). The Political Sources of Solidarity in Diverse Societies. In K. Banting and W. Kymlicka (Eds.). The Strains of Commitment, Oxford, UK: Oxford University Press.

Barber, B. R. (2004). Taking the Public out of Education: The Perverse Notion that American Democracy Can Survive without Its Public Schools. School Administrator, 61(5), 10.

Bator, F. M. (1958). The anatomy of market failure. The quarterly journal of economics, 72(3), 351-379.

Belfield, C., \& Levin, H. M. (2005). Vouchers and public policy: When ideology trumps evidence. American Journal of Education, 111(4), 548-567.

Bellah, R. N. (1967). Civil religion in America. Journal of the American Academy of Arts and Sciences, 96(1), 1-21.

Bozeman, B. (1987). All organization are public: Bridging public and private organizational theories. San Francisco: Jossey-Bass.

Bozeman, B. (2000). Bureaucracy and red tape. Cliffs, NJ: Prentice Hall.

Bryson, J. M., Crosby, B. C., \& Bloomberg, L. (2014). Public value governance: Moving beyond traditional public administration and the new public management. Public Administration Review, 74(4), 445-456.

Carnegie Corporation of New York. (2011). Carnegie review: A new civic mission of schools. Retrieved from: https://www.carnegie.org/media/filer_public/85/8b/858b7e5d-c53842e2-ae78-24471dce73d7/ccny_creview_2011_civic.pdf

Carnoy, M. \& McEwan, P.J. (2003). Does privatization improve education? The case of Chile's national voucher plan. In DN Plank and G Sykes (Eds). Choosing Choice: School Choice in International Perspective. New York: Teachers College Press.

Christie, C. (2007). Content analysis. In R. Baumeister \& K. Vohs (Eds.), Encyclopedia of social psychology (p. 176). Thousand Oaks, CA: SAGE

Congress, U. S. (1994). Goals 2000: Educate America Act. Public Law, 103227.

Corporation for National and Community Service (CNCS) and the National Conference on Citizenship. (2010). Civic Life in America: Key Findings on the Civic Health of the Nation. Washington, DC. 
Denhardt, R., Denhardt, J., \& Blanc, T.A. (2006). Public administration: An action orientation (5th ed.). Belmont, CA: Thomson-Wadsworth.

Devins, N. (1983). State Regulation of Christian Schools. J. Legis., 10, 351.

Downs, A., \& Rand Corporation. (1967). Inside bureaucracy. Boston: Little, Brown.

Dynarski, M. (2016). On negative effects of vouchers. Economic Studies at Brookings, 1.

Education Commission of the States (2017). 50 State Comparison: Vouchers. Retrieved from http://www.ecs.org/50-state-comparison-vouchers/

Finnigan, K. S. (2007). Charter school autonomy: The mismatch between theory and practice. Educational Policy, 21(3), 503-526.

Fleming, L. C. (2011). Civic participation: A curriculum for democracy. American Secondary Education, 40(1), 39-50.

Fleming, D. J., Mitchell, W., \& McNally, M. (2014). Can markets make citizens? School vouchers, political tolerance, and civic engagement. Journal of School Choice, 8(2), 213236.

Galston, W. A. (2007). Civic knowledge, civic education, and civic engagement: A summary of recent research. International Journal of Public Administration, 30(6-7), 623-642.

Goss, R. P. (1996). A distinct public administration ethics?. Journal of Public Administration Research and Theory, 6(4), 573-597.

Guardian of Democracy: The Civic Mission of Schools. (2011). Ed. Jonathan Gould. The Leonore Annenberg Institute for Civics of the Annenberg Public Policy Center at the University of Pennsylvania and the Campaign for the Civic Mission of Schools.

Heyneman, S.P. (2009). International Perspectives on School Choice.” In M. Berends, M.G. Springer, D. Ballou, and H.J. Walberg (Eds.). Handbook of Research on School Choice. London/New York: Routledge.

Hooghe, M. (2004). Political socialization and the future of politics. Acta Politica, 39(4), 331341.

Johnson, B. J. (2011). Creating civic bureaucrats. International Public Management Journal, 14(2), 157-192. 
Kahne, J., Chi, B., \& Middaugh, E. (2006). Building social capital for civic and political engagement: The potential of high-school civics courses. Canadian Journal of Education/Revue canadienne de l'éducation, 387-409.

Kennedy, S. S. (2001). Privatizing education: The politics of vouchers. Phi Delta Kappan, 82(6), 450-456.

Kennedy, S. S., \& Schultz, D. (2011). American public service: Constitutional and ethical foundations. Sudbury, MA: Jones \& Bartlett Learning.

Kennedy, S.S., Braun, E., \& Tynes, A. (2011, June 6). Civic Literacy: Charting the Dimensions and Consequences of a Civic Deficit. Retrieved from https://www.sheilakennedy.net/2011/06/civic-literacy-charting-the-dimensions-andconsequences-of-a-civic-deficit/

Koretz, D. (2017). The testing charade: Pretending to make schools better. Chicago, IL: University of Chicago Press.

Langton, K. P., \& Jennings, M. K. (1968). Political socialization and the high school civics curriculum in the United States. American Political Science Review, 62(3), 852-867.

Levin, H. M. (2002). A comprehensive framework for evaluating educational vouchers. Educational evaluation and policy analysis, 24(3), 159-174.

Lindblom, C. (1977). Politics and markets. NY: Basic Books.

Lopez, M. H., Levine, P., Both, D., Kiesa, A., Kirby, E., \& Marcelo, K. (2006). The 2006 civic and political health of the nation: A detailed look at how youth participate in politics and communities. Center for Information and Research on Civic Learning and Engagement.

Lubienski, C., \& Weitzel, P. (2010). The charter school experiment: Expectations, evidence, and implications. Cambridge, MA: Harvard Education Press.

Maxwell, T. A. (2018). Clarity of Purpose and the Freedom to Lead: An Exploration of Principal Autonomy in Colorado Charter Schools. University of Northern Colorado Dissertation

Moore, M. H. (1995). Creating public value: Strategic management in government. Harvard university press.

Morin, R. (2013). The most (and least) diverse countries around the world. Pew Research Center. 
Moulton, S., \& Feeney, M. K. (2010). Public service in the private sector: Private loan originator participation in a public mortgage program. Journal of Public Administration Research and Theory, 21(3), 547-572.

National Council for the Social Studies (NCSS). (2013). The College, Career, and Civic Life (C3) Framework for Social Studies State Standards: Guidance for Enhancing the Rigor of K-12 Civics, Economics, Geography, and History. Silver Spring, MD.

Newbold, S. (2011). No time like the present: Making rule of law and constitutional competence the theoretical and practical foundation for public administration graduate education curriculum. Journal of Public Affairs Education, 17(4), 465-481.

Patrick, B. (2013). Ethics and performance management: Assessing critical elements of no child left behind performance reforms. Public Integrity, 15(3), pp.221-242.

Peterson, P. E., Greene, J. P., Howell, W. G., \& McCready, W. (1998). Initial findings from an evaluation of school choice programs in Dayton, Ohio and Washington, D.C. Harvard University, Program on Education Policy and Governance. Occasional paper, October.

Prothero, S. (2007). Religious literacy: What every American needs to know- and doesn't. NY: Harper Collins Publishers.

Ravitch, D. (1974). The Great School Wars: New York City, 1805-1973: A History of the Public Schools as Battlefields of Social Change. NY: Basic Books.

Riccucci, N. (2010). Public administration: Traditions of inquiry and philosophies of knowledge. Washington DC: Georgetown University Press.

Rohr, J. (1998). Public service, ethics and constitutional practice. Lawrence, KS: University Press of Kansas

Rose, L. C., \& Gallup, A. M. (2000). The 32nd annual Phi Delta Kappa/Gallup poll of the public's attitudes toward the public schools. Phi Delta Kappa, 82(1), 41-58.

Rosenbloom, D. (1992). The Constitution as the basis for public administration ethics In P. Madsen \& J. M. Shafritz (Eds) Essentials of government ethics. NY: Meridian.

Sabharwal, M., Levine, H., \& D’Agostino, M. (2018). A conceptual content analysis of 75 years of diversity research in public administration. Review of Public Personnel Administration, 38(2), 248-267.

Samuelson, P. A. (1954). The pure theory of public expenditure. The Review of Economics and Statistics, 36(4), 387-389. 
Shapiro, S. \& Brown, C. (2018). A look at civic education in the United States. Retrieved from: https://www.aft.org/ae/summer2018/shapiro_brown

Sherrod, L. R., Torney-Purta, J., \& Flanagan, C. A. (2010). Handbook of research on civic engagement in youth. John Wiley \& Sons.

Shon, J. \& Hillman, S. (2015). Defining civic and citizenship education or: What is the good citizen? Hawai'i Educational Policy Center, University of Hawai'i at Mānoa. 2.

Stillings, C. (2006). Charter schools and no child left behind: Sacrificing autonomy for accountability. Journal of Education,186(2), 51-70.

Troen, S. K. (1975). The public and the schools: Shaping the St. Louis system, 1838-1920. Columbia, MO: University of Missouri Press.

Van der Wal, Z., Nabatchi, T., \& de Graf, G. (2015). From galaxy to universe? A crossdisciplinary review and analysis of public values publications from 1969-2012. American Review of Public Administration, 45(1), 13-28.

We the People: The Citizen and the Constitution (2017). We the People Overview. Retrieved from http://www.civiced.org/pdfs/WethePeopleOverview.pdf

Westheimer, J. \& Kahne, J. (2004). What kind of citizen? Educating for democracy. American Educational Research Journal, 41(2), 237-269.

\section{STATE STATUTES CITED}

AR Code $\S 6-41-807,2017$

Fla. Stat. §1002.42(2)(h), 2017

Fla. Stat. §1003.4282(3)(d), 2017

Fla. Stat. $\$ 1002.395(1)(c)$

Fla. Stat. §1003.41(2), 2017

La. R.S. Ann. §17:11, 2017

La. R.S. Ann. §17:274.1, 2017

Me. Rev. Stat. Ann. Title 20-A, §§4706, 2017

N.C. Gen. Stat. §115C-549, 2017

N.C. Gen. Stat. §115C-557, 2017

N.C. Gen. Stat. §§115C-554, 562, 2007Utah Code Ann. 53G-10-302(1), 2017

Vt. Admin. Code 7-1-2:2120, 2017

Vermont Statute 16 V.S.A. §906, 2017

Wis. Adm. Code P| 18.03, 2017 
Wis. Stat. §118.33(1)(a)1, 2017

16 VSA §906(a) and (b), 2017

511 IAC 7-32-21, 2017 
Table 1

Summary of Findings

\begin{tabular}{|c|c|c|}
\hline & $\begin{array}{c}\text { Codified Regulation of } \\
\text { Civics Curricula }\end{array}$ & Curricula Not Regulated \\
\hline Public & $\checkmark$ & $\checkmark$ \\
\hline Nonpublic & $\checkmark$ & $\checkmark$ \\
\hline Voucher & & \\
\hline
\end{tabular}




\section{Appendix}

School Choice Voucher Programs by State

\begin{tabular}{|l|l|}
\hline State & Name of the voucher program(s) \\
\hline Arkansas & Succeed Scholarship Program \\
\hline District of Columbia & D.C. Opportunity Scholarship Program \\
\hline Florida & $\begin{array}{l}\text { John M. McKay Scholarship for Students with Disabilities } \\
\text { Program }\end{array}$ \\
\hline Georgia & Georgia Special Needs Scholarship Program \\
\hline Indiana & Choice Scholarship Program \\
\hline Louisiana & $\begin{array}{l}\text { Student Scholarships for Educational Excellence; School Choice } \\
\text { Program for Certain Students with Exceptionalities }\end{array}$ \\
\hline Maine & Town Tuitioning \\
\hline Maryland & $\begin{array}{l}\text { Broadening Options and Opportunities for Students Today } \\
\text { Program }\end{array}$ \\
\hline Mississippi & $\begin{array}{l}\text { Nate Rogers Scholarship for Students with Disabilities; } \\
\text { Mississippi Speech-Language Therapy Scholarship for Students } \\
\text { with Speech-Language Impairments; Mississippi Dyslexia } \\
\text { Therapy Scholarship for Students with Dyslexia }\end{array}$ \\
\hline Oklahoma & $\begin{array}{l}\text { Opportunity Scholarship; Special Education Scholarships for } \\
\text { Children with Disabilities }\end{array}$ \\
\hline North Carolina & $\begin{array}{l}\text { Autism Scholarship Program; Cleveland Scholarship Program; } \\
\text { EdChoice Expansion Program; Educational Choice Scholarship } \\
\text { Program; Jon Peterson Special Needs Scholarship Program } \\
\text { Program }\end{array}$ \\
\hline Chio & \begin{tabular}{l} 
Carson Smith Scholarships for Students with Special Needs \\
\hline
\end{tabular} \\
\hline Utah & \\
\hline
\end{tabular}




\begin{tabular}{|l|l|}
\hline Vermont & Town Tuitioning \\
\hline Wisconsin & $\begin{array}{l}\text { Milwaukee Parental Choice Program; Racine Parental Private } \\
\text { School Choice Program; Special Needs Scholarship Program; } \\
\text { Wisconsin Parental Choice Program }\end{array}$ \\
\hline
\end{tabular}

Sources: Education Commission of the States (2017). 50 State Comparison: Vouchers. Retrieved from http://www.ecs.org/50-state-comparison-vouchers/; National Center for Education Statistics (2017). Table 4.7, States with voucher programs by state. Institute of Education Sciences, U.S. Department of Education. Retrieved from https://nces.ed.gov/programs/statereform/tab4_7.asp 
Appendix cont.

States with School Choice Voucher Programs

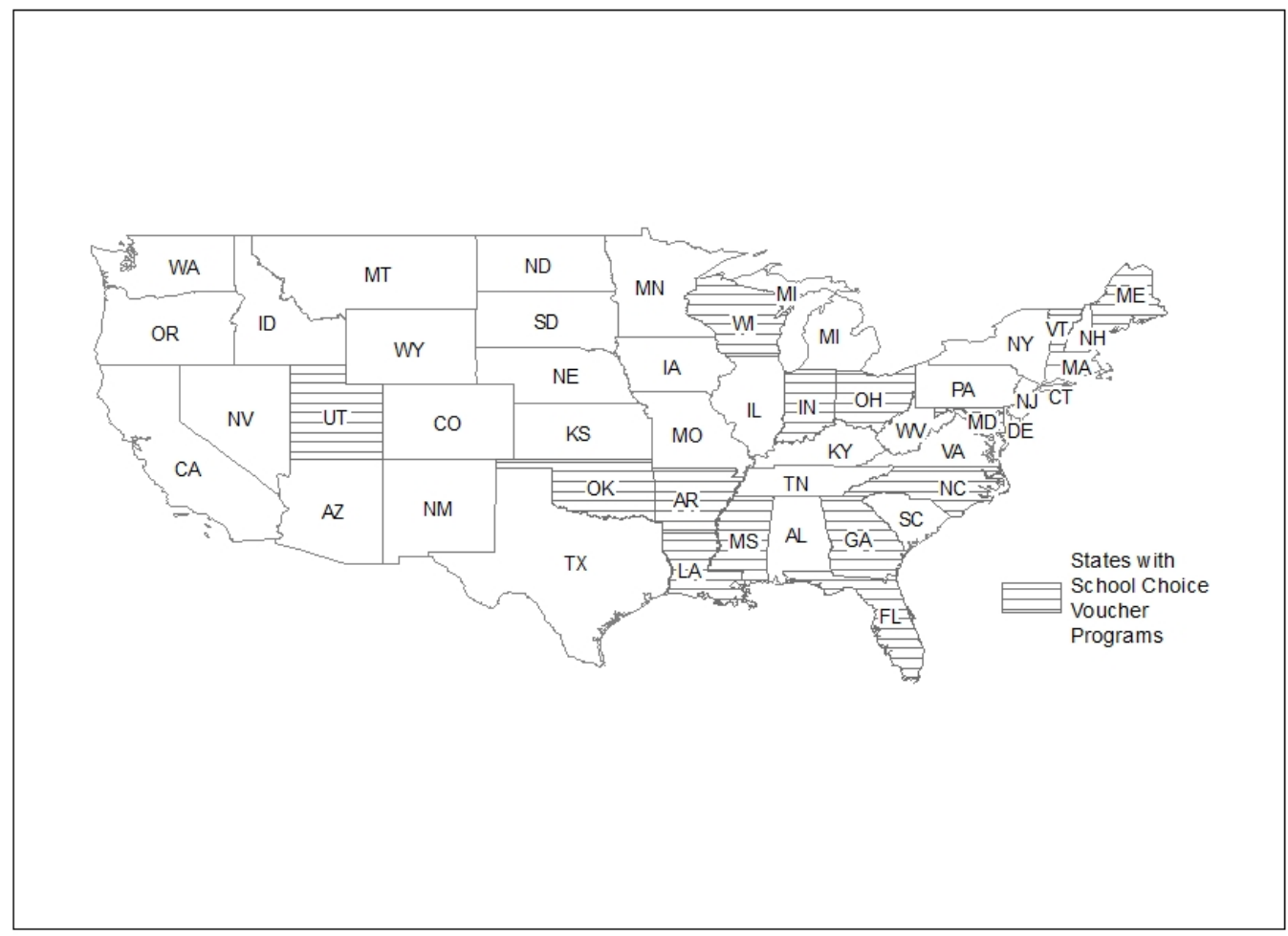




\section{Appendix cont.}

\section{Civics Requirements by State}

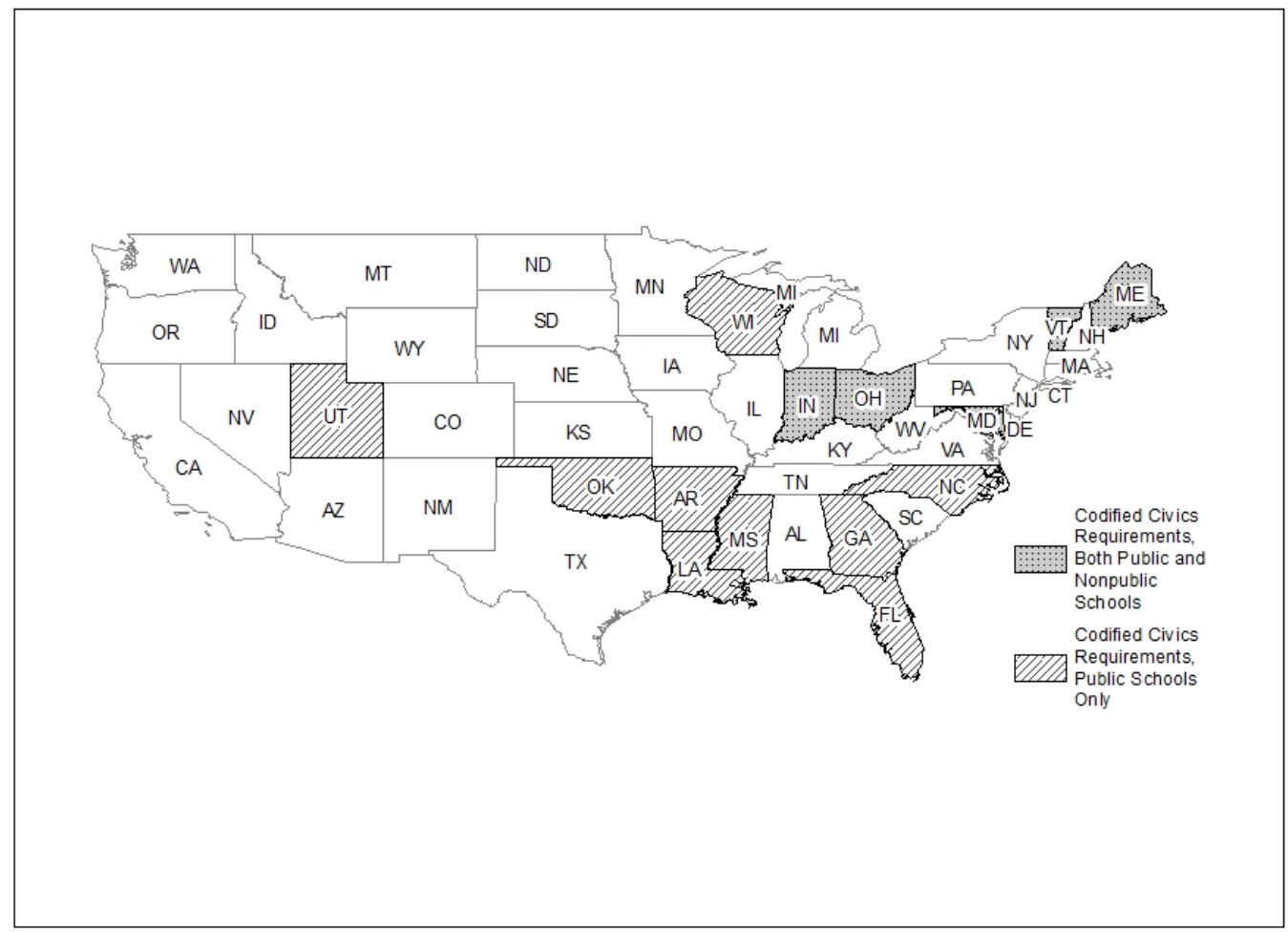

